\title{
Evaluating Mechanical Properties of Macro-Synthetic Fiber-Reinforced Concrete with Various Types and Contents
}

\author{
M. Daneshfar, ${ }^{a}$ A. Hassani, ${ }^{a, 1}$ M. R. M. Aliha, ${ }^{b}$ and F. Berto ${ }^{c}$ \\ a School of Civil and Environmental Engineering, Tarbiat Modares University, Tehran, Iran \\ ${ }^{\mathrm{b}}$ Welding and Joining Research Center, School of Industrial Engineering, Iran University of Science \\ and Technology (IUST), Tehran, Iran \\ c Department of Mechanical and Industrial Engineering, Norwegian University of Science and \\ Technology (NTNU), Trondheim, Norway \\ ${ }^{1}$ hassani@modares.ac.ir
}

УдК 539.4

\section{Оценка механических свойств бетона, армированного макросинтетичес- кими волокнами различного типа и содержимого}

\author{
М. Данешфар ${ }^{\mathrm{a}}$, А. Хассани ${ }^{\mathrm{a}}$, М. Р. М. Алиха ${ }^{\sigma}$, Ф. Бертов \\ а Факультет гражданского строительства и инженерной защиты окружающей среды, Универ- \\ ситет Тарбиат Модарес, Тегеран, Иран \\ ${ }^{6}$ Исследовательский центр по сварке и монтажу, Факультет промышленного инжиниринга, \\ Научно-технологический университет Ирана, Тегеран, Иран
в Механико-машиностроительный факультет, Норвежский университет естественных и техни- ческих наук, Тронхейм, Норвегия

Бетон как один из наиболее широко используемых строительных материалов характеризуется хрупкими свойствами. Добавление в бетон волокон различного типа и содержсиого влияет на податливость и механические характеристики бетона. Проведено экспериментальное исследование для оиенки влияния типа и содержимого полимерных волокон на механические свойства армированного волокнами бетона (прочность при изгибе, прочность при сжатии, косвенный предел прочности при растяжении, модуль упругости). Образць из бетона были выполнены с применением трех различных типов полимерного волокна (скрученное, щепкообразные прутки, фибриллированное) с содержанием 0.2, 0.4 и 0.6 об.\% соответственно. Установлено, что, добавление волокна в образиы из бетона повышает предель прочности на изгиб и растяжение на 19.6-81.69\% и 0.84-34.29\% соответственно и понижает предел прочности при сжатии и модуль упругости на 4.57-26.32\% и 12.48-37.08\% соответственно. Бетон, содержащий скрученные волокна и волокна в виде щчепкообразных прутков, несмотря на различные типы волокон, имеет одинаковые изгибные характеристики.

Ключевые слова: армированный волокнами бетон, прочность при сжатии, модуль упругости, прочность при изгибе.

Introduction. Fiber-reinforced concrete is a type of concrete that is mixed with fibers. Various types of fibers are used to produce fiber-reinforced concrete, which include glass, polymer, carbon, and steel [1].

In the present research, macro-synthetic polymer fibers were used. Some of the consequences of applying macro-synthetic fibers in concrete include reduced shrinkage of fresh and hardened concrete, increased ductility, vulnerability and hardness of concrete, 
increased strength against fatigue stresses, increased durability and lifetime of concrete, improved concrete mechanical properties (tensile strength, flexural strength, etc.), control of secondary/thermal cracks of concrete, preventing the in-depth propagation of cracks, post-cracking chargeability and reduced permeability against chloride and sulfate ions [2]. To date, numerous studies have been conducted on fiber-reinforced concrete, most of which have been focused on the evaluation of fiber-reinforced concrete using steel and plastic fibers or their combination. Banthia and Yoo [3] conducted a study on the mechanical properties of high-performance fiber-reinforced concrete and reported that the use of various types of steel fibers could improve concrete's mechanical properties. Further, adding macro-steel fibers to the conventional concrete improved the tensile strength, strain capacity and flexural strength compared to the micro-steel fibers. Alberti et al. [4] studied self-compacting fiber-reinforced concrete by combining polyolefin and steel fibers, and reported that the combination of polyolefin and steel fibers had higher performance in terms of rupture toughness and flexure than use of a single type of fiber. Vibhuti et al. [5] performed an experimental study on the mechanical properties of fiber-reinforced concrete for pavement and evaluated the effect of adding single and hybrid fibers to concrete. Accordingly, they reported that the hybrid fibers led to improved compressive strength, as compared to single fibers, while hybrid fibers also significantly improved the flexural strength. Eswari [6] conducted an experiment on the flexural performance of the hybrid fiber-reinforced concrete and evaluated the effect of different contents of polymer and steel fibers on the flexural strength and performance of the fiber-reinforced concrete specimens. Thus, he reported that adding fibers could improve them in the evaluated parameters compared to the conventional concrete. Singh et al. [7] studied the flexural strength and toughness of fiber-reinforced concrete with different percentages of polypropylene, steel fibers and total percentage of $1 \%$, and reported that combining $75 \%$ of the steel fibers and $25 \%$ of polypropylene fibers yielded better results in terms of compressive strength, flexural strength and flexural toughness. Vairagade and Deshpande [8] carried out a research on the tensile and compressive behaviors of the fibrillated polypropylene fiberreinforced concrete specimens, the results of which indicated the increased 7- and 28-day compressive and tensile strengths. Dawood and Ramli [9] studied the effect of fibers on properties of high-strength concrete and showed that adding the steel fiber with content of $1 \%$ could improve the compressive strength by $10 \%$. Rizzuti and Bencardino [10] investigated effect of the fiber content on compressive and flexural strength and reported that addition of the fibers had no explicit effect on the compressive strength. Lee et al. [11] carried out a research on the compressive behavior of the steel fiber-reinforced concrete and showed that addition of the fibers had no significant effect on the compressive strength and elastic modulus. Sukumar and John [12] studied the effect of adding the steel, glass, and polypropylene fibers on concrete strength. They reported that the flexural, compressive, and indirect tensile strength was increased by adding the fibers. Patil and Kulkarni [13] investigated and compared the effects of the steel and glass fibers on flexural and compressive strength. They reported that in a certain range of fiber content, the compressive and flexural strength would be increased. Pawade et al. [14] investigated the steel fiber performance on the elastic modulus and compressive strength and reported that increasing the fiber content would lead to an increase in the compressive strength and elastic modulus by 17 and 8\%, respectively. Richardson [15] studied the effect of adding the polypropylene fibers on compressive strength and reported that addition of the fibers would result in the reduced compressive strength. Mohite and Shinde [16] experimentally assessed the effect of steel fibers and showed that addition of the fibers would lead to a slight increase (15\%) in the compressive strength. Gowri and AngelineMary [17] investigated the effect of the glass fibers on mechanical properties of concrete and showed that the compressive and tensile strength would be slightly increased. Alsadey and Salem [18] conducted a study on the effect of the polypropylene fibers on concrete strength and 
reported that addition of the fibers would increase the concrete's compressive strength by $12 \%$. Prathap and Siva Reddy [19] conducted an experiment on the elastic modulus by changing the steel fiber content in fiber-reinforced concrete and reported that by increasing the fiber content, the elastic modulus would be increased. Widodo et al. [20] investigated the effect of adding the compound (polypropylene and steel) fibers on mechanical properties of concrete and reported that adding the compound fibers would lead to the increase in compressive strength, elastic modulus, tensile strength, and modulus of rupture by $22,24,222$, and $187 \%$, respectively.

Regarding the studies on this field and the difference in the obtained results, in the present study, the researchers evaluated the effect of content and type of the macrosynthetic fiber on mechanical properties of the fiber-reinforced concrete, including flexural and compressive strength, indirect tensile strength, and elastic modulus, in order to investigate the effect of adding fibers on the compressive strength and elastic modulus. The given parameters in the present study, including flexural strength (ASTM C78), compressive strength (BS 1881-116), elastic modulus (ASTM C 469), and indirect tensile strength (ASTM C496-71), were measured. The fibers were added to the concrete mixture in three twisted, barchip, and fibrillated forms with the volume fractions of $0.2,0.4$, and $0.6 \%$, respectively. For each of the given parameters, three specimens were constructed and the averaging results were inserted in the relevant tables.

\section{Laboratory Program.}

1.1. Test Variables. To evaluate flexural strength, compressive strength, indirect tensile strength, and elastic modulus, the concrete mixture was designed based on ACI 211.1 standard [21]. In order to investigate effect of the fibers, all the concrete specimens were made with the same mix design in three different types, including twisted, barchip, and fibrillated, and with three volume fractions of $0.2,0.4$, and $0.6 \%$. Different types of fibers are shown in Fig. 1, and also the concrete mix design is represented in Table 1. Table 2 represents the geometrical and physical properties of the fiber used in the research [22]. Table 3 shows the geometrical properties of the concrete beam specimens.

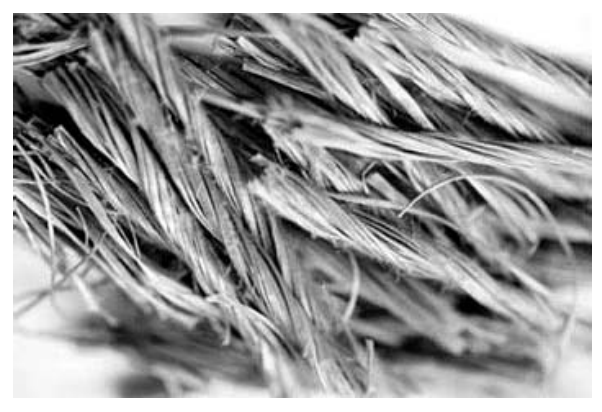

a

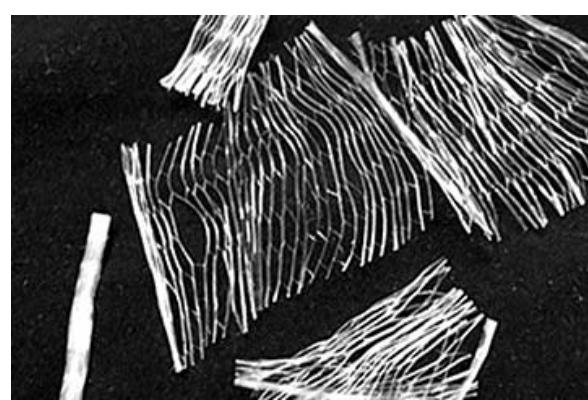

b

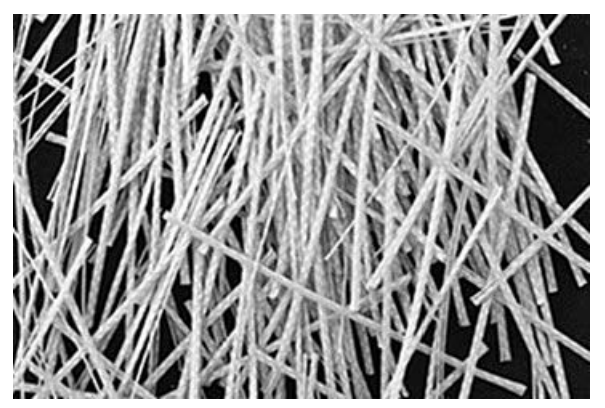

C

Fig. 1. Twisted (a), fibrillated (b), and barchip (c) fibers. 


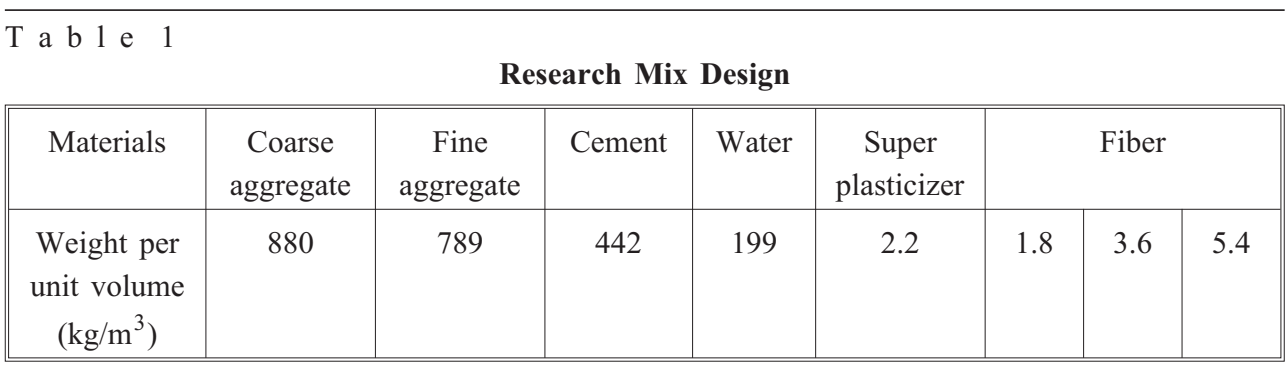

T a b 1 e 2

Geometrical and Physical Properties of Fibers

\begin{tabular}{|c|c|c|c|c|c|c|}
\hline Material & \multicolumn{2}{|c|}{ Shape } & $\begin{array}{l}\text { Resistance } \\
\text { to acidic } \\
\text { and alkaline } \\
\text { environments }\end{array}$ & $\begin{array}{c}\text { Water } \\
\text { absorption }\end{array}$ & $\begin{array}{l}\text { Melting } \\
\text { point } \\
\left({ }^{\circ} \mathrm{C}\right)\end{array}$ & $\begin{array}{l}\text { Flash } \\
\text { point } \\
\left({ }^{\circ} \mathrm{C}\right)\end{array}$ \\
\hline \multirow[t]{3}{*}{ Polyolefin } & \multicolumn{2}{|c|}{$\begin{array}{l}\text { Macro/single strand } \\
\text { of fine string sticking } \\
\text { together }\end{array}$} & Excellent & - & 120 & 590 \\
\hline & $\begin{array}{l}\text { Elastic } \\
\text { modulus } \\
(\mathrm{GPa})\end{array}$ & $\begin{array}{l}\text { Tensile } \\
\text { strength } \\
(\mathrm{MPa})\end{array}$ & $\begin{array}{c}\text { Diameter } \\
(\mathrm{mm})\end{array}$ & $\begin{array}{l}\text { Length } \\
\text { (mm) }\end{array}$ & $\begin{array}{l}\text { Density } \\
\left(\mathrm{g} / \mathrm{cm}^{3}\right)\end{array}$ & Color \\
\hline & 4.2 & $570-660$ & 0.3 & 38 & $0.91-0.96$ & gray \\
\hline
\end{tabular}

$\mathrm{T}$ a b 1 e 3

Nominating Specimens

\begin{tabular}{|c|c|c||}
\hline Name of specimens & Shape of fiber & Fiber volume fraction (vol.\%) \\
\hline B2 & Barchip & 0.2 \\
\hline B4 & Barchip & 0.4 \\
\hline B6 & Barchip & 0.6 \\
\hline F2 & Fibrillate & 0.2 \\
\hline F4 & Fibrillate & 0.4 \\
\hline F6 & Fibrillate & 0.6 \\
\hline T2 & Twisted & 0.2 \\
\hline T4 & Twisted & 0.4 \\
\hline T6 & Twisted & 0.6 \\
\hline N & - & 0 \\
\hline
\end{tabular}

1.2. Specimen Structure. Using fiber-reinforced concrete, the beam and cubic specimens were constructed to evaluate the flexural and compressive strengths, respectively. Moreover, the indirect tensile strength and elastic modulus were evaluated by a cylindrical specimen. The fibers used in this study were of three types, namely: in fibrillated, twisted, and barchip, with $0.2,0.4$, and 0.6 vol.\%. Firstly, cement was mixed with sand and fibers and, then, the water mixed with super plasticizer was added to the mixture, in order for the 
fibers to be uniformly distributed within the mixture. Afterwards, the fiber-reinforced concrete mixture was poured into the prepared molds.

\subsection{Laboratory Settings and Measurements.}

1.3.1. Flexural Strength. In accordance with ASTM C78 Standard [23], the four-point loading and beam dimensions were selected as $350 \times 100 \times 100 \mathrm{~mm}$. The distance between the two upper and the two lower supports was set as 100 and $300 \mathrm{~mm}$, respectively. The vertical load was applied at the loading rate of $0.5 \mathrm{~mm} / \mathrm{min}$.

1.3.2. Compressive Strength. Compressive strength is an important parameter to determine the material's performance during its service life. According to BS 1881-116 Standard [24], compressive loading and cubic specimens with the dimensions of $100 \times 100 \times 100 \mathrm{~mm}$ were selected.

1.3.3. Elastic Modulus. Elastic modulus of the concrete specimens is obtained according to ASTM C 469 Standard [25]. The test specimens were cylindrical with the dimensions of $150 \times 300 \mathrm{~mm}$. Figure 2 shows the specimen and device used to measure the elastic modulus.

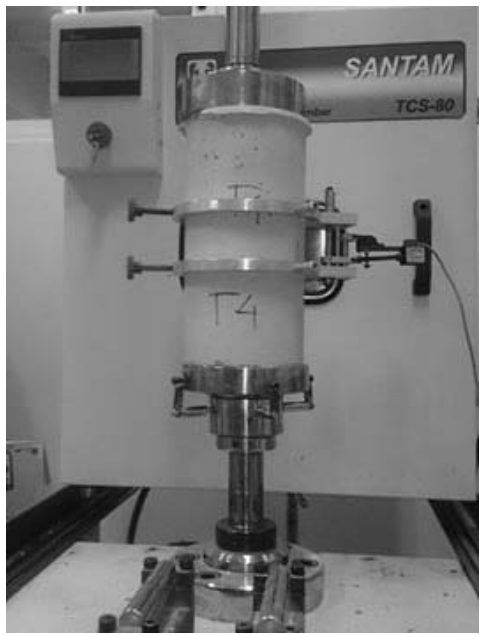

Fig. 2. Setting the device and measuring elastic modulus.

1.3.4. Indirect Tensile Strength. Indirect tensile (bisection or Brazilian) test was performed in accordance with ASTM C496-71 Standard [26] using cylindrical specimens with the dimensions of $150 \times 300 \mathrm{~mm}$. The compressive load was applied at the rate of 0.011 to $0.023 \mathrm{MPa}$ and the maximum rupture force was measured. Figure 3 depicts the device setting for measuring the specimen indirect tensile strength.

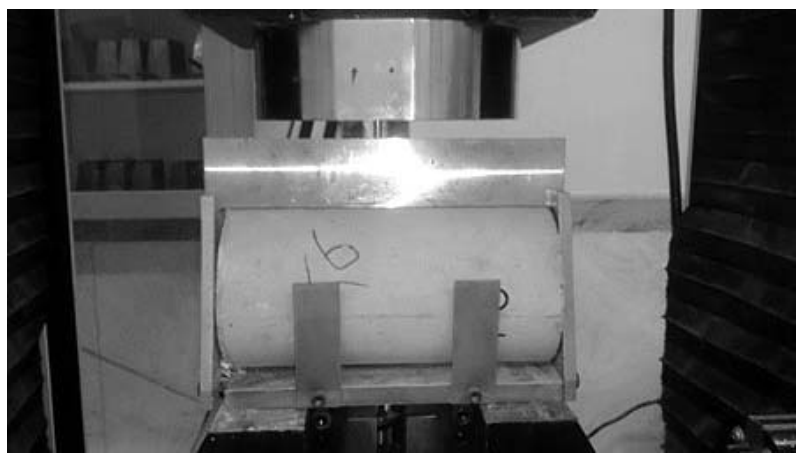

Fig. 3. Setting of the device and measuring the indirect tensile strength. 


\section{Experimental Results and Discussion.}

2.1. Flexural Strength. In order to obtain the flexural strength of the fiber-reinforced concrete specimens, the specimens were made in accordance with the ASTM C78 Standard and underwent the four-point flexural loading. The load-displacement curve of the span was derived and the maximum flexural strength was assessed via the maximum flexural force through Eq. (1),

$$
R=\frac{P L}{b d^{2}} \text {. }
$$

Table 4 and Fig. 4 present the flexural strength results for various fiber-reinforced concrete specimens.

$\mathrm{T}$ a b 1 e 4

Results for Flexural Strength of Concrete Specimens

\begin{tabular}{|c|c|c|c|}
\hline Specimen & $P, \mathrm{~N}$ & $R, \mathrm{MPa}$ & $\begin{array}{c}\text { Percent } \\
\text { increase (\%) }\end{array}$ \\
\hline $\mathrm{N}$ & $13,399.76$ & 4.02 & 0 \\
\hline B2 & $16,026.67$ & 4.81 & 19.60 \\
\hline B4 & $18,377.48$ & 5.51 & 37.15 \\
\hline B6 & $18,797.02$ & 5.64 & 40.28 \\
\hline T2 & $16,610.00$ & 4.98 & 23.88 \\
\hline T4 & $17,906.13$ & 5.37 & 33.58 \\
\hline T6 & $20,401.70$ & 6.12 & 52.23 \\
\hline F2 & $20,325.36$ & 6.10 & 51.68 \\
\hline F4 & $21,974.15$ & 6.59 & 63.99 \\
\hline F6 & $24,345.86$ & 7.30 & 81.69 \\
\hline
\end{tabular}

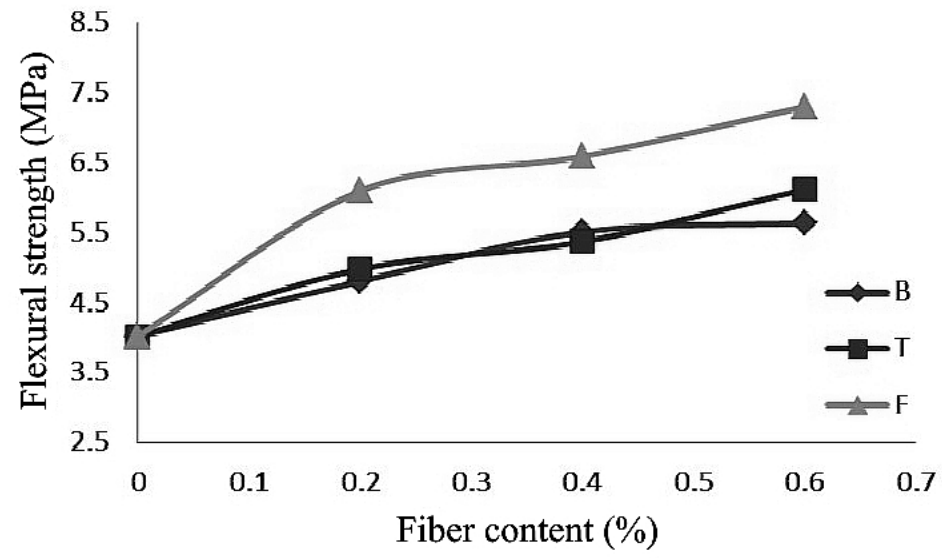

Fig. 4. Flexural strength versus fiber content.

2.2. Compressive Strength. The compressive strength tests were performed in accordance with the BS 1881-116 Standard, and their results are shown in Table 5 and Fig. 5. 
$\mathrm{T}$ a b 1 e 5

Results on the Compressive Strength of Cubic Concrete Specimens

\begin{tabular}{|c|c|c|}
\hline Specimen & $\begin{array}{c}\text { Compressive strength } \\
(\mathrm{MPa})\end{array}$ & $\begin{array}{c}\text { Percent change } \\
(\%)\end{array}$ \\
\hline N & 67.52 & -7.43 \\
\hline B2 & 62.50 & -4.57 \\
\hline B4 & 64.43 & -6.55 \\
\hline B6 & 63.10 & -6.10 \\
\hline T2 & 63.40 & -4.62 \\
\hline T4 & 64.40 & -6.40 \\
\hline T6 & 63.20 & -20.47 \\
\hline F2 & 53.70 & -15.80 \\
\hline F4 & 56.85 & -26.32 \\
\hline F6 & 49.75 & \\
\hline
\end{tabular}

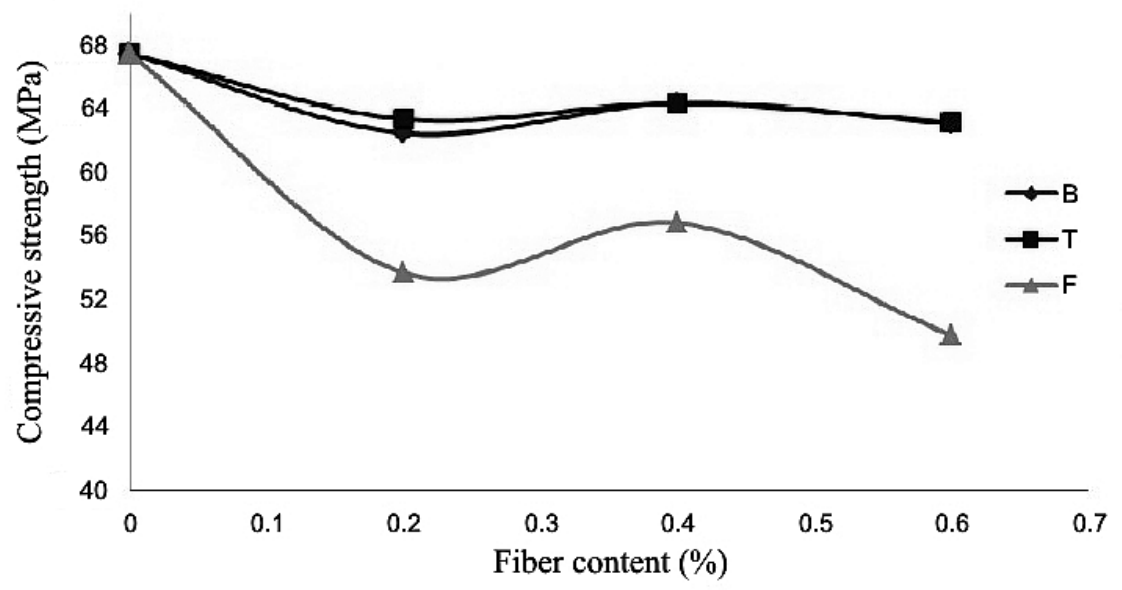

Fig. 5. Diagram of compressive strength of cubic specimens versus fiber content.

2.3. Elastic Modulus. Elastic modulus can be obtained directly from the initial slope of the stress-strain curve. To obtain the curve, the load is gradually applied at the rate of 2-3 MPa per second as long as the $P$-value reaches the value of maximum force. Then, the load is reduced at the same rate, at which it had been increased. This loading and unloading process is repeated for three times. After completion of the three loading cycles, the fourth cycle is applied at the above loading rate up to $P_{0}$ (approximately corresponding to the stress value of $5 \mathrm{MPa}$ ). The load is maintained for thirty seconds; meanwhile, the displacement of $\delta_{b}$ from displacement sensors is measured. Then, the load is increased to $P$-value, which is approximately 0.4 of the maximum value, and kept for thirty seconds. Similarly, $\delta_{a}$ is read from the displacement sensors and, after calculating the read mean difference $\left(\delta_{a}-\delta_{b}\right)$, the results are recorded as $\delta_{4}$. Afterwards, the loading is reduced to $P_{0}$ and, then, the 5th loading cycle is applied similar to the initial load. The fifth loading cycle is also performed through the above method. The corresponding displacement is recorded, as well as the mean value $\left(\delta_{5}\right)$ obtained via the displacement variations obtained 
from the sensor. The specimen loading is shown in Fig. 6. The elastic modulus is calculated using Eq. (2):

$$
E=\frac{P-P_{0}}{A} \frac{l}{\delta_{n}}
$$

Table 6 and Fig. 7 illustrate the elastic moduli of concrete specimens versus the fiber content variation.

$\mathrm{T}$ a b 1 e 6

Elastic Moduli of Different Concrete Specimens

\begin{tabular}{|c|c|c|}
\hline Specimen & Elastic modulus $(\mathrm{MPa})$ & Percent change (\%) \\
\hline N & 32,798 & 0 \\
\hline B2 & 27,341 & -16.64 \\
\hline B4 & 28,504 & -13.09 \\
\hline B6 & 26,784 & -18.34 \\
\hline T2 & 27,941 & -14.81 \\
\hline T4 & 28,704 & -12.48 \\
\hline T6 & 26,635 & -18.79 \\
\hline F2 & 22,411 & -31.67 \\
\hline F4 & 24,704 & -24.68 \\
\hline F6 & 20,635 & -37.08 \\
\hline
\end{tabular}

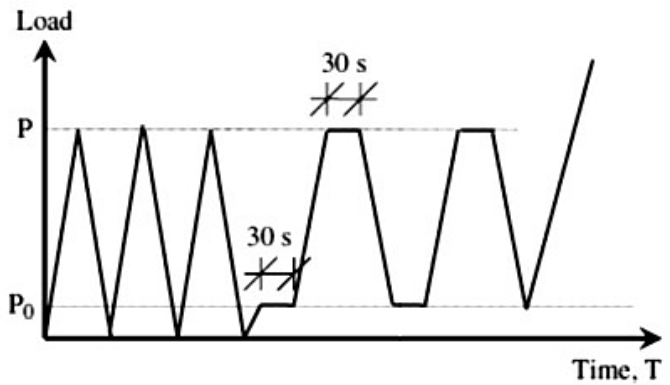

Fig. 6. The loading scheme for measuring the elastic modulus [25].

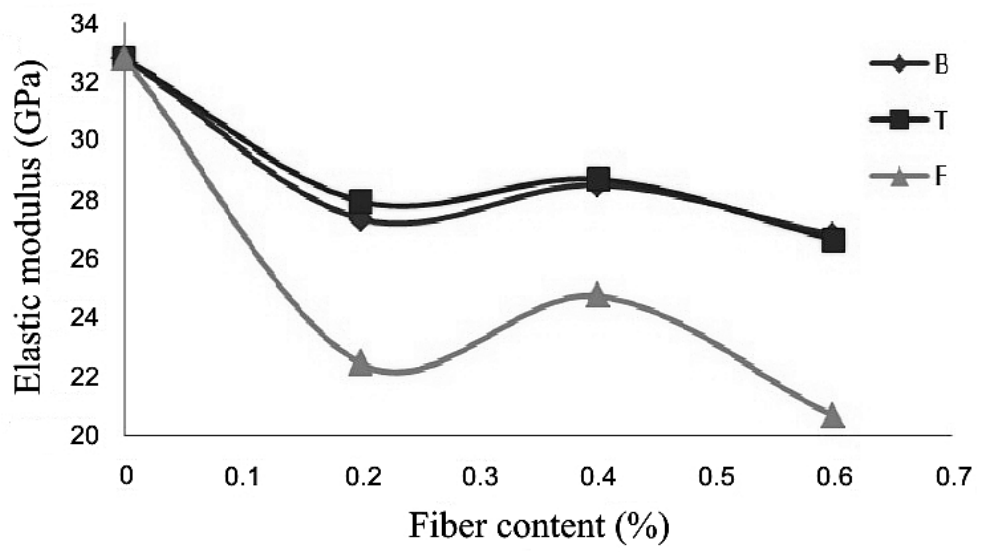

Fig. 7. Elastic modulus versus fiber content variation. 
2.4. Indirect Tensile Strength. According to procedure described in the ASTM C496-71 Standard [26] or [27], after recording the maximum rupture force, the indirect tensile strength is obtained from Eq. (3):

$$
T=\frac{2 P}{\pi l d},
$$

where $T, P, l$, and $d$ are defined, respectively, as tensile strength (MPa), maximum applied load indicated by the testing machine $(\mathrm{N})$, length $(\mathrm{mm})$, and diameter $(\mathrm{mm})$.

The obtained strength estimation results are presented in Table 7 and Fig. 8.

T a b 1 e 7

\section{Indirect Tensile Strength Assessment Results}

\begin{tabular}{|c|c|c|c|}
\hline Specimen & $P, N$ & Tensile strength $(\mathrm{MPa})$ & Increase $(\%)$ \\
\hline B2 & $235,825.9$ & 3.34 & 0.84 \\
\hline B4 & $245,348.1$ & 3.47 & 4.92 \\
\hline B6 & $308,107.6$ & 4.36 & 31.75 \\
\hline F2 & $248,021.3$ & 3.51 & 6.06 \\
\hline F4 & $273,748.1$ & 3.87 & 17.06 \\
\hline F6 & $314,042.4$ & 4.45 & 34.29 \\
\hline T2 & $238,074.6$ & 3.37 & 1.81 \\
\hline T4 & $243,263.5$ & 3.44 & 4.02 \\
\hline T6 & $303,595.0$ & 4.30 & 29.82 \\
\hline N & $233,919.5$ & 3.31 & 0.03 \\
\hline
\end{tabular}

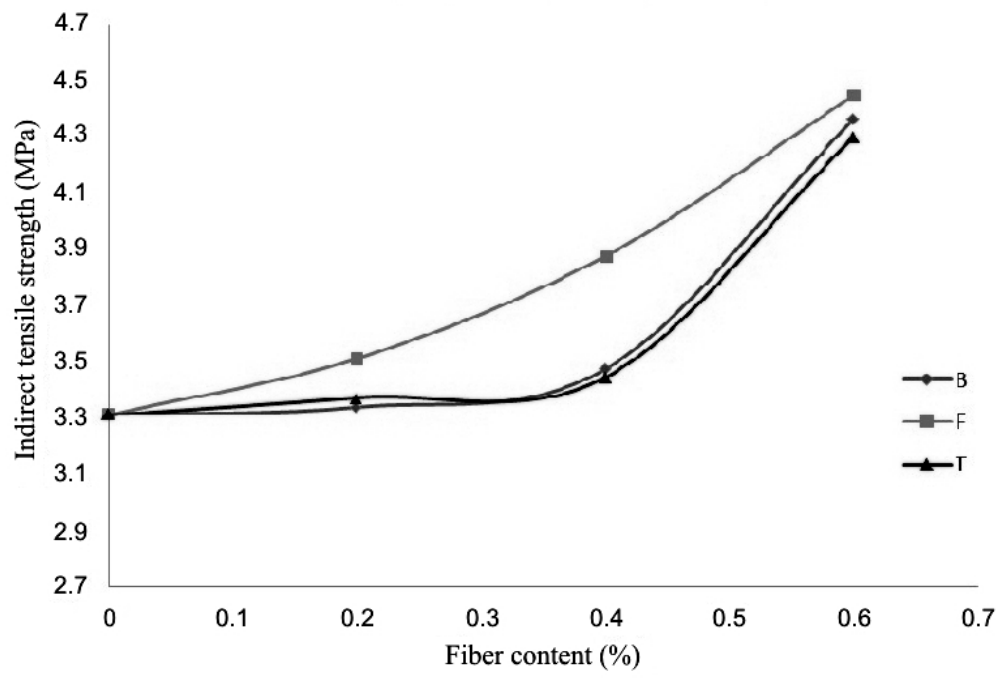

Fig. 8. Tensile strength versus with fiber content.

Conclusions. In this study, the flexural strength, compressive strength, elastic modulus, and indirect tensile strength were measured for fiber-reinforced concrete specimens with the same mix design, three types and three different contents of fibers, and also effect of the fibers on these parameters was investigated. 
The main results of this study are as follows:

1. The addition of fibers with the volume fraction of $0.2-0.6 \%$ to the concrete mixture:

(i) increased flexural strength of the specimens containing barchip, twisted, and fibrillated fibers by $19.6-40.28 \%, 23.88-52.23 \%$, and $51.68-81.69 \%$, respectively;

(ii) reduced the compressive strength of the specimens containing fibrillated, barchip, and twisted fibers by $15-26 \%, 4-7 \%$, and $4-6 \%$, respectively;

(iii) reduced the elastic modulus of the specimens containing barchip, twisted, and fibrillated fibers by $13.09-18.34 \%, 12.48-18.79 \%$, and $24.68-37.08 \%$, respectively;

(iv) increased the indirect tensile strength of the specimens containing barchip, twisted, and fibrillated fibers by $0.84-31.75 \%, 1.81-29.82 \%$, and $6.06-34.29 \%$, respectively.

2. Despite the difference between the barchip and twisted fibers, results of the parameters obtained for these fibers were close.

3. Since the increased fiber content makes the specimen mixing quite problematic, it is recommended to use the fiber content in the range of 0.2-0.6 volume percentages.

4. With regard to the obtained results, the use of fibers for structures such as concrete pavement, in which flex and tension are significantly important, is shown to improve the flexural and tensile strength, leading to the increased durability, loading capacity, and structure lifetime. Nevertheless, the addition of fibers would reduce the compressive strength and elastic modulus, which should be taken into consideration in the structural design.

\section{Резюме}

Бетон як один із будівельних матеріалів, що найбільш широко використовується, має крихкі властивості. Добавляння в бетон різного типу і вмісту волокон впливає на його піддатливість і механічні характеристики. Експериментально досліджено вплив типу і вмісту полімерних волокон на механічні характеристики армованого волокнами бетону (міцність при згині і при стиску, умовна границя міцності при розтязі, модуль пружності). Зразки з бетону виготовляли 3 добавлянням трьох типів полімерного волокна (скручене 0,2 об.\%, тріскоподібні прутики 0,4 об.\%, фібрильоване 0,6 об.\%). Установлено, що добавляння волокна в зразки з бетону підвищує границі міцності при згині і розтязі на $19,6 \ldots 81,69 \%$ та $0,84 \ldots 34,29 \%$ відповідно і знижує границю міцності при стиску і модуль пружності на 4,57...26,32\% і 12,48...37,08\% відповідно. Назважаючи на різні типи волокон (скручене, тріскоподібні прутики), бетон має однакові характеристики при згині.

1. Zongjin Li, Advanced Concrete Technology, John Wiley \& Sons, Inc., Hoboken, NJ (2011).

2. R. D. Tolêdo Filho and M. A. Sanjuán, "Effect of low modulus sisal and polypropylene fibre on the free and restrained shrinkage of mortars at early age," Cement Concrete Res., 29, No. 10, 1597-1604 (1999).

3. D. Y. Yoo and N. Banthia, "Mechanical properties of ultra-high-performance fiberreinforced concrete: A review," Cement Concrete Comp., 73, 267-280 (2016).

4. M. G. Alberti, A. Enfedaque, J. C. Gálvez, "Fibre reinforced concrete with a combination of polyolefin and steel-hooked fibres," Compos. Struct., 171, 317-325 (2017).

5. Rajarajeshwari B. Vibhuti, Radhakrishna, and N. Aravind, "Mechanical properties of hybrid fiber reinforced concrete for pavements," IJRET: Int. J. Res. Eng. Technol., Nov., 244-247 (2013), DOI: 10.15623/ijret.2013.0213043. 
6. S. Eswari, "Experimental investigation on flexural performance of hybrid fibre reinforced concrete," Int. Res. J. Eng. Technol. (IRJET), 02, No. 03, 1772-1776 (2015).

7. S. P. Singh, A. P. Singh, and V. Bajaj, "Strength and flexural toughness of concrete reinforced with steel - polypropylene fiber," Asian J. Civil Eng. (Build. Hous.), 11, No. 4, 495-507 (2010).

8. V. Vairagade, K. S. Kene, and N. V. Deshpande, "Investigation on compressive and tensile behavior of fibrillated polypropylene fibers reinforced concrete," Int. J. Eng. Res. Appl. (IJERA), 2, No. 3, 1111-1115 (2012).

9. E. T. Dawood and M. Ramli, "Effects of the fibers on the properties of high strength flowing concrete," KSCE J. Civ. Eng., 18, No. 6, 1704-1710 (2014).

10. L. Rizzuti and F. Bencardino, "Effects of fibre volume fraction on the compressive and flexural experimental behaviour of SFRC," Contemp. Eng. Sci., 7, No. 8, 379390 (2014).

11. S. C. Lee, J. H. Oh, and J. Y. Cho, "Compressive behavior of fiber-reinforced concrete with end-hooked steel fibers," Materials, 8, No. 4, 1442-1458 (2015).

12. A. Sukumar and E. John, "Fiber addition and its effect on concrete strength," Int. J. Innov. Res. Adv. Eng. (IJIRAE), 1, No. 8, 144-149 (2014).

13. R. K. Patil and D. B. Kulkarni, "Comparative study of effect of basalt, glass and steel fiber on compressive and flexural strength of concrete," IJRET: Int. J. Res. Eng. Technol., 03, No. 06, 436-438 (2014).

14. P. Y. Pawade, P. B. Nagarnaik, and A. M. Pande, "Performance of steel fiber on standard strength concrete in compression," Int. J. Civil Struct. Eng., 2, No. 2, 483492 (2011).

15. A. E. Richardson, "Compressive strength of concrete with polypropylene fibre additions," Struct. Survey, 24, No. 2, 138-153 (2006).

16. D. B. Mohite and S. B. Shinde, "Experimental investigation on effect of different shaped steel fibers on compressive strength of high strength concrete," IOSR J. Mech. Civil Eng. (IOSR-JMCE), 6, No. 4, 24-26 (2013).

17. R. Gowri and M. AngelineMary, "Effect of glass wool fibres on mechanical properties of concrete," Int. J. Eng. Trend. Technol. (IJETT), 4, No. 7, 3045-3048 (2013).

18. S. Alsadey and M. Salem, "Influence of polypropylene fiber on strength of concrete," Amer. J. Eng. Res. (AJER), 5, No. 7, 223-226 (2016).

19. T. Prathap and L. Siva Reddy, "Experimental study of modulus of elasticity due to change in steel fiber reinforced concrete and size of aggregates," Int. J. Eng. Res. Gen. Sci., 4, No. 5, 130-136 (2016).

20. S. Widodo, I. Satyarno, and S. Tudjono, "Effects of hybrid polypropylene-steel fiber addition on some hardened properties of lightweight concrete with pumice breccia aggregate," ISRN Civil Eng., 2012, Article ID 475751 (2012), DOI: 10.5402/2012/ 475751.

21. ACI 211.1. Standard Practice for Selecting Proportions for Normal, Heavyweight, and Mass Concrete, American Concrete Institute (1991).

22. ASTM D7508/D7508M-10(2015). Standard Specification for Polyolefin Chopped Strands for Use in Concrete, ASTM International, West Conshohocken, PA (2015).

23. C78-02. Standard Test Method for Flexural Strength of Concrete (Using Simple Beam with Third-Point Loading), ASTM International, West Conshohocken, PA (2006). 
24. BS 1881-116: 1983. Testing Concrete. Method for Determination of Compressive Strength of Concrete Cubes, British Standards Institution (1983).

25. ASTM C469/C469M-14. Standard Test Method for Static Modulus of Elasticity and Poisson's Ratio of Concrete in Compression, ASTM International, West Conshohocken, PA (2014).

26. ASTM C 496/C 496M-04. Standard Test Method for Splitting Tensile Strength of Cylindrical Concrete Specimens, ASTM International, West Conshohocken, PA (2004).

27. M. R. M. Aliha, "Indirect tensile test assessments for rock materials using 3-D disc-type specimens," Arab. J. Geosci., 7, No. 11, 4757-4766 (2014).

Received 12. 06. 2017 